\title{
Efficacy of Different Antihypertensive Drugs among newly Diagnosed Hypertensive Patient in Dhulikhel Hospital
}

\section{Humagain S, Koju R}

Department of Cardiology

Dhulikhel Hospital, Kathmandu University Hospital

Dhulikhel, Kavre, Nepal.

\section{Corresponding Author}

Sanjaya Humagain

Department of Cardiology

Dhulikhel Hospital, Kathmandu University Hospital Dhulikhel, Kavre, Nepal.

E-mail: sanjayahumagain@hotmail.com

\section{Citation}

Humagain S, Koju R. Efficacy of Different Antihypertensive Drugs among newly Diagnosed Hypertensive Patient in Dhulikhel Hospital. Kathmandu Univ Med J 2015;51(3):212-5.

\section{ABSTRACT}

\section{Background}

Cardiovascular disease represents the largest burden on global health, important modifiable risk factor being hypertension. Difference in response to antihypertensive medication depending on ethnic group is well recognized. There is very few data regarding this difference in the South Asian population especially from Nepal.

\section{Objective}

The aim of this study is to find out which antihypertensive medication has better efficacy in our population.

\section{Method}

One seventy two newly diagnosed hypertensive patients who presented to cardiology OPD were included. Blood Pressure (BP) was recorded in both arms at least three times. Patients were counseled for lifestyle and dietary modification and were prescribed one of the three drugs Hydrochlorthiazide $25 \mathrm{mg}$ or Amlodipine 5 $\mathrm{mg}$ or Enalapril $5 \mathrm{mg}$. Patients were called back in 4-6 weeks time and Blood Pressure was recorded in similar manner.

\section{Result}

Out of 172 patients, 97 were male and 75 female. The mean age was $55.49 \pm 1.03$ years. Mean Systolic BP before treatment was $156.2 \pm 10.6 \mathrm{~mm}$ of $\mathrm{Hg}$ and Mean Diastolic BP before treatment was $100.5 \pm 6.8$ with no statistically significant difference among different groups. However Systolic BP reduction was $14.6 \pm 5.1$, $21.9 \pm 5.9$ and $21.8 \pm 7.4$ by Hydrochlorthiazide , Amlodipine and Enalapril respectively. Diastolic BP reduction was $8.8 \pm 2.5,14.2 \pm 2.8$ and $14.3 \pm 2.9$ by Hydrochlorthiazide, Amlodipine and Enalapril respectively.

\section{Conclusion}

Amlodipine and Enalapril are equally effective in controlling BP in our population. Hydrochlorthiazide is less effective than both Amlodipine and Enalapril.

\section{KEY WORDS}

Amlodipine, antihypertensive drugs, efficacy, enalapril, hydrochlorthiazide. 


\section{INTRODUCTION}

Cardiovascular disease represents $10 \%$ of the global burden of disease and mortality and morbidity due to cardiovascular disease is expected to rise by more than $33 \%$ over the coming two or three decades. ${ }^{1,2}$ Hypertension defined as systolic BP of more than $140 \mathrm{mmHg}$ and diastolic BP of more than $90 \mathrm{~mm} \mathrm{Hg}$ is one of the most important modifiable risk factor for cardiovascular disease. ${ }^{3}$ The prevalence of hypertension is in rising trend in Nepal. The prevalence of hypertension has increased by three fold in twenty five years. In study done at the same place it was found that prevalence of hypertension was $6 \%$ in 1981 and $18 \%$ in $2006 .^{4}$

Difference in response to antihypertensive agents depending on different ethnic group is well recognized. Joint National Committee (JNC) IV published in 1988 was the first to recommend consideration of race and ethnicity while prescribing antihypertensive drugs. ${ }^{5}$ There are many trials which have shown the difference among the black and the white population. Blacks of African origin have propensity for a higher salt sensitivity, and markedly lower plasma renin levels, compared with whites of Caucasian origin. While south Asians, because of a higher prevalence of central obesity and insulin resistance, are likely to have hypertension mainly driven by a higher sympathetic activity. ${ }^{6}$

There is very few data regarding this difference in the South Asians. From Nepal there is almost no data. So it is important for us to find out which antihypertensive medication is best for the patient to control BP.

\section{METHODS}

It is a prospective comparative study carried out at Dhulikhel Hospital, Kathmandu University Hospital. A newly diagnosed hypertensive patient who presented to cardiology OPD from January $1^{\text {st }} 2015$ to $30^{\text {th }}$ April 2015 were included in the study. BP was recorded according to standard method in both arms at least three times and average was recorded. All the patient were counseled for lifestyle and dietary modification and were prescribed one of the three drugs Hydroclorthiazide $25 \mathrm{mg}$ or Amlodipine $5 \mathrm{mg}$ or Enalapril $5 \mathrm{mg}$. Patients were called back for follow up in 4-6 weeks time and BP was recorded in similar manner.

\section{Inclusion criteria}

i) Newly diagnosed hypertensive patient of age 40 to 80 who presented to cardiology OPD.

\section{Exclusion criteria}

i) Patient having Systolic BP more than $180 \mathrm{~mm}$ of $\mathrm{Hg}$ and / or Diastolic BP more than $110 \mathrm{~mm}$ of $\mathrm{Hg}$.

ii) Patient suspected to have secondary hypertension. iii) Patient having compelling indication or contra-indication for any of the drug.

iv) Patient who were not willing to be the part of study or did not come for follow up in 4-6 weeks time, or were not compliant to prescribed drug.

Statistical analysis was done using SPSS 20.0 and ANOVA was applied wherever applicable.

\section{RESULTS}

Out of 172 patients, 97 were male and 75 female. The mean age was $55.49 \pm 1.03$ years. Distribution of patient according to gender and antihypertensive medication is shown in Fig. 1 and similarly distribution of patient according to age and antihypertensive medication is shown in Fig. 2.

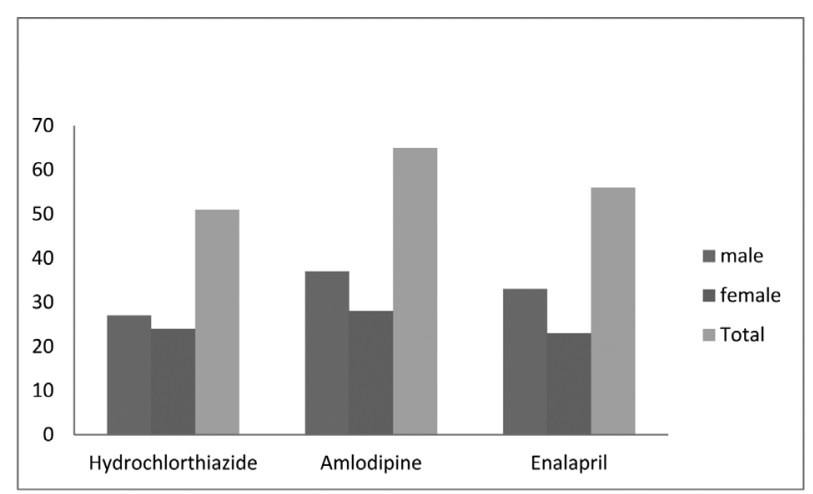

Figure 1. Distribution of Patient according to gender and antihypertensive drug.

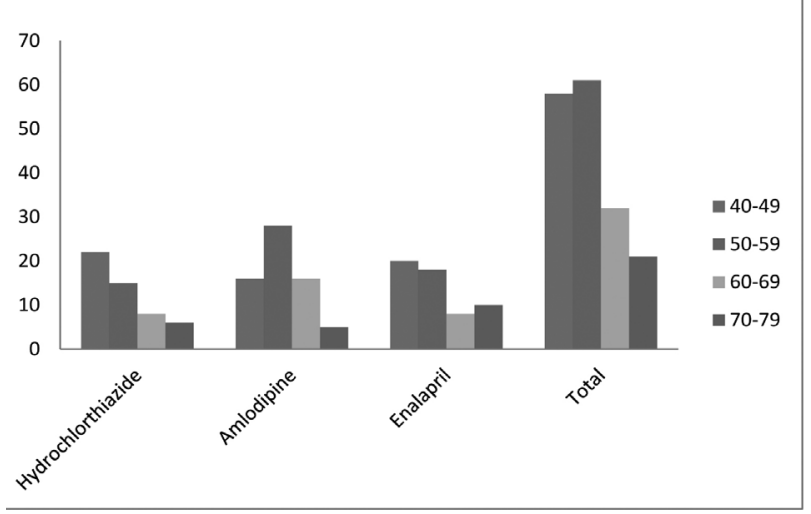

Figure 1. Distribution of patient according to age and antihypertensive drug.

Mean Systolic BP before treatment was $156.2 \pm 10.6 \mathrm{~mm}$ of $\mathrm{Hg}$ with no significant difference all three groups. Mean Diastolic BP before treatment was $100.5 \pm 6.8 \mathrm{~mm}$ of $\mathrm{Hg}$ with no statistically significant difference among different groups. However as shown in table 1, 2 and 3 the average Systolic BP reduction was $14.6 \pm 5.1 \mathrm{~mm}$ of $\mathrm{Hg}, 21.9 \pm 5.9$ $\mathrm{mm}$ of $\mathrm{Hg}$ and $21.8 \pm 7.4 \mathrm{~mm}$ of $\mathrm{Hg}$ by Hydrochlorthiazide, Amlodipine and Enalapril respectively. Diastolic BP reduction was $8.8 \pm 2.5 \mathrm{~mm}$ of $\mathrm{Hg}, 14.2 \pm 2.8 \mathrm{~mm}$ of $\mathrm{Hg}$ and $14.3 \pm 2.9 \mathrm{~mm}$ of $\mathrm{Hg}$ by Hydrochlorthiazide, Amlodipine and Enalapril respectively. The efficacy in reducing both Systolic 
Table 1. Comparison between Hydrochlorthiazide $\mathbf{2 5} \mathrm{mg}$ and Amlodipine $5 \mathrm{mg}$

\begin{tabular}{llll|} 
& $\begin{array}{l}\text { Hydrochlorthiazide } \\
\mathbf{2 5} \mathbf{~ m g}\end{array}$ & $\begin{array}{l}\text { Amlodipine } \\
\mathbf{5} \mathbf{~ m g}\end{array}$ & $\begin{array}{l}\mathbf{P} \\
\text { value }\end{array}$ \\
\hline $\begin{array}{l}\text { Systolic BP before } \\
\text { treatment } \\
\text { (mean } \pm \text { SD)/mmHG }\end{array}$ & $156.2 \pm 9.8$ & $155.8 \pm 10.7$ & 0.870 \\
\hline $\begin{array}{l}\text { Systolic BP after } \\
\text { treatment } \\
\text { (mean } \pm \text { SD)/mmHG }\end{array}$ & $141.6 \pm 9.6$ & $133.9 \pm 7.5$ & 0.000 \\
\hline $\begin{array}{l}\text { Reduction in Systolic BP } \\
\text { (mean } \pm S D) / m m H G\end{array}$ & $14.6 \pm 5.1$ & $21.9 \pm 5.9$ & 0.000 \\
\hline $\begin{array}{l}\text { Diastolic BP before } \\
\text { treatment } \\
\text { (mean } \pm S D) / m m H G\end{array}$ & $101.5 \pm 7.5$ & $102 \pm 5.8$ & 0.700 \\
\hline $\begin{array}{l}\text { Diastolic BP after } \\
\text { treatment } \\
\text { (mean } \pm S D) / m m H G\end{array}$ & $92.7 \pm 7.2$ & & \\
\hline $\begin{array}{l}\text { Reduction in Diastolic BP } \\
\text { (mean } \pm S D) / m m H G\end{array}$ & $8.8 \pm 2.5$ & $14.2 \pm 2.8$ & 0.000 \\
\hline
\end{tabular}

Table 2. Comparison between Hydrochlorthiazide $\mathbf{2 5} \mathbf{~ m g}$ and Enalapril $5 \mathrm{mg}$

\begin{tabular}{|c|c|c|c|}
\hline & $\begin{array}{l}\text { Hydrochlorthiazide } \\
25 \mathrm{mg}\end{array}$ & $\begin{array}{l}\text { Enalapril } \\
5 \mathrm{mg}\end{array}$ & $\begin{array}{l}P \\
\text { value }\end{array}$ \\
\hline $\begin{array}{l}\text { Systolic BP before } \\
\text { treatment } \\
(\text { mean } \pm \text { SD)/mmHG }\end{array}$ & $156.2 \pm 9.8$ & $\begin{array}{l}156.6 \\
\pm 11.4\end{array}$ & 0.856 \\
\hline $\begin{array}{l}\text { Systolic BP after } \\
\text { treatment } \\
\text { (mean } \pm \text { SD)/mmHG }\end{array}$ & $141.6 \pm 9.6$ & $134.8 \pm 8.8$ & 0.000 \\
\hline $\begin{array}{l}\text { Reduction in Systolic BP } \\
(\operatorname{mean} \pm S D) / m m H G\end{array}$ & $14.6 \pm 5.1$ & $21.8 \pm 7.4$ & 0.000 \\
\hline $\begin{array}{l}\text { Diastolic BP before } \\
\text { treatment } \\
\text { (mean } \pm \text { SD)/mmHG }\end{array}$ & $101.5 \pm 7.5$ & $100.6 \pm 6.3$ & 0.325 \\
\hline $\begin{array}{l}\text { Diastolic BP after } \\
\text { treatment } \\
\text { (mean } \pm \text { SD)/mmHG }\end{array}$ & $92.7 \pm 7.2$ & $86.3 \pm 6.9$ & 0.008 \\
\hline $\begin{array}{l}\text { Reduction in Diastolic BP } \\
(\text { mean } \pm S D) / m m H G\end{array}$ & $8.8 \pm 2.5$ & $14.3 \pm 2.9$ & 0.000 \\
\hline
\end{tabular}

Table 3. Comparison between Amlodipine $\mathbf{5} \mathbf{~ m g}$ and Enalapril $5 \mathrm{mg}$

\begin{tabular}{|c|c|c|c|}
\hline & $\begin{array}{l}\text { Amlodipine } \\
5 \mathrm{mg}\end{array}$ & $\begin{array}{l}\text { Enalapril } \\
5 \mathrm{mg}\end{array}$ & $P$ value \\
\hline $\begin{array}{l}\text { Systolic BP before treat- } \\
\text { ment }(\text { mean } \pm S D) / m m H G\end{array}$ & $155.8 \pm 10.7$ & $156.6 \pm 11.4$ & 0.730 \\
\hline $\begin{array}{l}\text { Systolic BP after treat- } \\
\text { ment } \\
(\text { mean } \pm S D) / m m H G\end{array}$ & $133.9 \pm 7.5$ & $134.8 \pm 8.8$ & 0.587 \\
\hline $\begin{array}{l}\text { Reduction in Systolic BP } \\
(\text { mean } \pm S D) / m m H G\end{array}$ & $21.9 \pm 5.9$ & $21.7 \pm 7.4$ & 0.920 \\
\hline $\begin{array}{l}\text { Diastolic BP before treat- } \\
\text { ment }(\text { mean } \pm S D) / m m H G\end{array}$ & $102 \pm 5.8$ & $100.6 \pm 6.3$ & 0.224 \\
\hline $\begin{array}{l}\text { Diastolic BP after treat- } \\
\text { ment }(\text { mean } \pm S D) / m m H G\end{array}$ & $87.8 \pm 6.1$ & $86.3 \pm 6.9$ & 0.226 \\
\hline $\begin{array}{l}\text { Reduction in Diastolic BP } \\
(\text { mean } \pm S D) / m m H G\end{array}$ & $14.2 \pm 2.8$ & $14.3 \pm 2.9$ & 0.857 \\
\hline
\end{tabular}

and Diastolic BP is similar with Amlodipine and Enalapril. However Hydrochlorthiazide has less efficacy in comparison to Amlodipine ( $p 0.000$ ) and Enalapril ( $p$ 0.000).

\section{DISCUSSION}

Difference in response to antihypertensive agents depending on different ethnic group is well recognized. The clinical recognition of such differences followed the 1982 Veterans Affairs (VA) Cooperative Study Group finding that $62 \%$ of whites and $54 \%$ of blacks achieved BP goal with propranolol, while such goal was attained with hydrochlorothiazide in $55 \%$ of whites and $71 \%$ of blacks. ${ }^{7}$ Blacks respond slightly better than whites to diuretics and CCBs, while whites respond slightly better than blacks to ACE inhibitors and $\beta$-blockers. ${ }^{8}$ In our study we found that our population responds better to CCB and ACEI than Hydrochlorthiazide.

Trials with black and Hispanic participants (ALLHAT, INVEST, VALUE) found similar primary outcomes, but ALLHAT found a greater magnitude of benefit for blacks on diuretic therapy compared with nonblacks. ${ }^{9-11}$ Our study suggests that we respond like nonblacks as BP control was significantly less with HCTZ. PROGRESS trial compared Asians with nonAsians, reporting that angiotensin converting enzyme inhibitors were equally effective for preventing stroke in both groups. ${ }^{12}$ In three studies conducted exclusively in Asians (JMIC-B, FEVER, NICS-EH), calcium channel blockers were effective in preventing cardiovascular outcome. ${ }^{13-15}$ Though we did not look at the cardiovascular outcome in our study we looked at controlling BP which is an important risk factor to prevent cardiovascular outcome.

In one of the study conducted in India, when antihypertensive medication in diabetic patient was compared the Systolic and Diastolic BP reduction by enalapril monotherapy was similar to our study. ${ }^{16}$ In another study where efficacy of different antihypertensive drugs were compared as a monotherapy or combined therapy, monotherapy drug efficacy is similar to our study. ${ }^{17}$ One of the sub group major trial, ASCOT trial which compared South Asians with white and black population, showed better response to angiotensin converting enzyme inhibitor (ACEI) and calcium channel blocker (CCB) then diuretics. ${ }^{18}$ So similar to these large studies our study also shows CCB and ACEI to be more effective in controlling BP.

$\mathrm{BP}$ recording was not done by the same person which could vary a little. BP recording was not done by the same sphygmomanometer which could also vary a little.

\section{CONCLUSION}

From our study we can conclude that both Amlodipine and Enalapril are equally effective in controlling BP in our population. Hydrochlorthiazide is less effective than both Amlodipine and Enalapril. So while choosing first 
line antihypertensive medication we should choose either Amlodipine or Enalapril but not Hydrochlorthiazide.

\section{REFERENCES}

1. World Health Organization: The Global Burden Of Disease: 2004 Update Geneva: WHO; 2008.

2. The World Health Organization: World Health Statistics 2008 Geneva: The World Health Organization; 2008.

3. Lewington S, Clarke R, Qizilbash N, et al. Age-specific relevance of usual blood pressure to vascular mortality: a meta-analysis of individual data for one million adults in 61 prospective studies. Lancet 2002, 360(9349):1903-13.

4. Vaidya A, Pokharel PK, Karki P, Nagesh S. Exploring the iceberg of hypertension: A community based study in an eastern Nepal town. Kathmandu Univ Med J. 2007; 5(19): 349-59.

5. The 1988 report of the Joint National Committee on Detection, Evaluation, and Treatment of High Blood Pressure. Arch Intern Med. 1988; 148(5): 1023-38.

6. Laragh $\mathrm{JH}$. Vasoconstriction-volume analysis for understanding and treating hypertension: the use of renin and aldosterone profiles. Am J Med. 1973; 55(3): 261-74.

7. Comparison of propranolol and hydrochlorothiazide for the initial treatment of hypertension. II. Results of long-term therapy. Veterans Administration Cooperative Study Group on Antihypertensive Agents. JAMA 1982; 248(16): 2004-11.

8. Brewster LM, van Montfrans GA, Kleijnen J. Systematic review: antihypertensive drug therapy in black patients. Ann Intern Med 2004; 141(8): 614-27.

9. Major Outcomes in High-Risk Hypertensive Patients Randomized to Angiotensin-Converting Enzyme Inhibitor or Calcium Channel Blocker vs Diuretic. The Antihypertensive and Lipid-Lowering Treatment to Prevent Heart Attack Trial (ALLHAT) FREE. The ALLHAT Officers and Coordinators for the ALLHAT Collaborative Research Group. JAMA. 2002; 288(23): 2981-2997. doi:10.1001/jama.288.23.2981.

10. Zanchetti A, Julius S, Kjeldsen $S$, et al. Outcomes in subgroups of hypertensive patients treated with regimens based on valsartan and amlodipine: An analysis of findings from the VALUE trial. $J$ Hypertens. 2006; 24(11): 2163-2168.
However we cannot comment on combination of drugs from this study.

11. Pepine CJ, Handberg EM, Cooper-DeHoff RM, et al. A calcium antagonist vs a non-calcium antagonist hypertension treatment strategy for patients with coronary artery disease. The International Verapamil-Trandolapril Study (INVEST): a randomized controlled trial. JAMA. 2003; 290(21): 2805-16.

12. Effects of a perindopril-based blood pressure lowering regimen on cardiac outcomes among patients with cerebrovascular disease PROGRESS Collaborative Group. Eur Heart J 2003;24 (5): 475-484. doi: 10.1016/S0195-668X(02)00804-7.

13. Yui $\mathrm{Y}$, Sumiyoshi $\mathrm{T}$, Kodama $\mathrm{K}$, et al. Comparison of nifedipine retard with angiotensin converting enzyme inhibitors in Japanese hypertensive patients with coronary artery disease: the Japan Multicenter Investigation for Cardiovascular Diseases-B (JMIC-B) randomized trial. Hypertens Res. 2004; 27(3): 181-91.

14. Liu L, Zhang Y, Liu G, Li W, Zhang X, Zanchetti A. The Felodipine Event Reduction (FEVER) Study: a randomized long-term placebo controlled trial in Chinese hypertensive patients. J Hypertens. 2005;23(12): 2157-72.

15. Kuramoto K. Randomized Double-Blind Comparison of a Calcium Antagonist and a Diuretic in Elderly Hypertensives. Hypertension. 1999; 34: 1129-33. doi: 10.1161/01.HYP.34.5.1129.

16. Beluah S, Uma MR, Balaji SR. Efficacy and Tolerability of Different Antihypertensive Drugs in Diabetic Patients with Mild to Moderate Hypertension in a Multi Speciality Hospital - A Prospective Comparative Study. Indian Journal of Pharmacy Practice. 2012;5(1): 21-7.

17. Yasmeen N, Varma RK, Siddiqua SS, Donepudi A. Efficacy and Tolerability of Different Antihypertensive Drugs in Patients with Mild to Moderate Hypertension in a Tertiary Care Hospital - A Prospective, Comparative Study. Archives of Applied Science Research 2011;3(1):436-443

18. Gupta AK, Poulter NR, Dobson J, et al. Ethnic differences in blood pressure response to first and second-line antihypertensive therapies in patients randomized in the ASCOT trial. Am J Hypertens 2010, 23:1023-30. 